\title{
Chemical versus mechanical inhibition of fouling in the red alga Dilsea carnosa
}

\author{
G. M. Nylund*, H. Pavia \\ Department of Marine Ecology, Tjärnö Marine Biological Laboratory, Göteborg University, 45296 Strömstad, Sweden
}

\begin{abstract}
In this study, we used field experiments in natural populations to test whether the low degree of fouling found naturally on the red alga Dilsea carnosa (Schmidel) O. Kuntze (1893) is due to chemical inhibition by antifouling metabolites. Extracts with concentrations volumetrically equivalent to whole algal tissue were incorporated into stable gels, which served as settlement substrata for potential fouling organisms. The gels were placed in the field during several time periods, covering all seasons. We also investigated the fouling intensity on living $D$. carnosa plants to be able to compare fouling on algae with fouling on gels. The extracts inhibited recruitment of a few fouling organisms, but they were not effective against the dominant bryozoan fouling species Electra pilosa and Membranipora membranacea. Furthermore, a relatively high number of these species occasionally recruited onto $D$. carnosa plants. Hence, chemical inhibition of fouling could not explain the low degree of fouling of bryozoan species found naturally on D. carnosa. Instead, based on field observations showing that $D$. carnosa is able to shed its epidermis, we hypothesised that the low degree of fouling is primarily due to cuticle peeling, whereby the alga sloughs off the outermost cell layer in order to remove associated fouling organisms. This hypothesis was tested in a field survey in which $D$. carnosa plants were marked and surveyed for about $5 \mathrm{mo}$. The results show that individual algae that experienced a radical drop in their fouling cover had distinct traces of cuticle peeling. Hence, this study suggests that the dominant fouling organisms are not chemically inhibited by $D$. carnosa. Instead, the low degree of fouling found naturally on $D$. carnosa is probably a consequence of a mechanical defence, whereby the alga sloughs off the outermost cell layer in order to remove associated epibiota.
\end{abstract}

KEY WORDS: Epibiosis $\cdot$ Antifouling $\cdot$ Cuticle peeling $\cdot$ Chemical defence $\cdot$ Epiphytes $\cdot$ Dilsea carnosa Resale or republication not permitted without written consent of the publisher

\section{INTRODUCTION}

In marine environments, the availability of unoccupied surfaces is essential for recruitment of a wide array of benthic organisms. One important source of substrata for colonisation of organisms is benthic marine macroalgae (seaweeds). Many seaweed species have large surface areas that constitute a significant proportion of the available surface in hard subtidal habitats (Seed 1985). These seaweeds are often relatively long-lived and stable in relation to the longevity of most epibiotic species. Besides surfaces for attachment, seaweeds provide an array of resources for epibiota including food supply, permanent or temporary shelter and sediment traps (Williams \& Seed
1992). Several studies have documented a largely negative effect of fouling organisms on their seaweed hosts. For example, fouling may increase the drag on the host and result in dislodgement from the substrata (Dixon et al. 1981, D'Antonio 1985), decrease resource availability and growth (D'Antonio 1985, Brawley 1992, Hurd et al. 2000), and damage host tissue by mechanical anchoring (Gonzalez \& Goff 1989), by enhancing breakage (Dixon et al. 1981, D'Antonio 1985) and by influencing the palatability of the host to herbivores (Bernstein \& Jung 1979, Wahl \& Hay 1995, Karez et al. 2000).

While some seaweeds are heavily fouled, other species in the same habitat are rarely epiphytised, indicating the presence of defence mechanisms against foul- 
ing. Seaweeds have different strategies to avoid being overgrown by other organisms. Examples of antifouling mechanisms are physical, such as sloughing of surface layers of host algae (e.g. Johnson \& Mann 1986, Keats et al. 1997), and chemical, whereby secondary metabolites that prevent settlement and growth of fouling organisms are produced. Seaweeds are rich in secondary metabolites (e.g. Tringali 1997, Faulkner 2002) and the literature shows that many algal species produce metabolites that have inhibitory effects on certain fouling organisms. For example, metabolites from brown algae reduce settlement and normal development of the common fouling bryozoan species Bugula neritina (Schmitt et al. 1995, Walters et al. 1996, Steinberg et al. 1998), inhibit metamorphosis of larvae of the polychaete Hydroides elegans (Walters et al. 1996, Lau \& Qian 1997), inhibit settlement of cyprid larvae of the barnacle Balanus improvisus (Wikström \& Pavia 2004), and inhibit spore settlement of the green alga Enteromorpha prolifera (Cho et al. 2001). Furthermore, metabolites from some red algae inhibit settlement of cyprid larvae of the barnacles Balanus amphitrite and B. improvisus (de Nys et al. 1995, Konig et al. 1999, Nylund \& Pavia 2003), larvae of B. neritina and H. elegans (Walters et al. 1996, Steinberg et al. 1998), as well as the settlement and germling development of gametes of the green alga Ulva lactuca (de Nys et al. 1995, Steinberg et al. 1998). Additionally, some green algal species produce settlement-inhibiting metabolites against certain fouling invertebrates and algae (Walters et al. 1996, Steinberg et al. 1998). However, the role of these compounds or extracts as fouling deterrents under natural conditions is in most cases unknown (but see Steinberg et al. 2001). Most of the experiments on antifouling activity have been conducted in the laboratory, testing extracts or pure compounds on only 1 or a few fouling species, often placed in small volumes of static seawater. Although results obtained from still water assays can be useful, the ecological relevance of these types of studies is questionable because they do not incorporate ecologically realistic flow regimes into the design. Furthermore, many antifouling compounds have a narrow spectrum in effectiveness, and prevention of fouling by one kind or organism may be supplanted by fouling of another type under natural conditions (Rittschof 2001).

The aim of this study was to investigate the antifouling property of the sublittoral red alga Dilsea carnosa. Based on years of diving experience in Swedish waters, this alga is commonly known to have low epibiotic cover compared to co-occurring algae. This indicates the presence of some kind of defence mechanism against fouling, and since many seaweeds are rich in secondary metabolites (e.g. Tringali 1997, Faulkner 2002), we hypothesised that the low degree of fouling found on D. carnosa is a result of production of metabolites that inhibit settlement and recruitment of fouling organisms. This hypothesis was tested in field experiments in which crude extracts of $D$. carnosa were incorporated into stable gels that served as settlement substrata for potential fouling organisms (cf. Henrikson \& Pawlik 1995). This method allowed us to test the effects of the extracts on a natural assemblage of fouling invertebrate larvae and algal spores under realistic flow conditions. We also investigated the fouling intensity on living $D$. carnosa plants found in the vicinity of the experimental gels. This procedure gave us the opportunity to compare fouling on algae with fouling on gels, and potentially to avoid drawing erroneous conclusions about the function of the extracts as natural antifoulants arising from differences between gels and algae in surface concentrations of compounds, and in physical properties of the surfaces, etc. The results of the field experiments showed that chemical inhibition of fouling is not a satisfactory explanation of the low degree of fouling found naturally on $D$. carnosa. Instead, based on observations during the field experiments, we hypothesised that this is primarily a result of cuticle peeling, whereby the alga sloughs off the outermost cell layer in order to remove the fouling community. This hypothesis was tested in a field survey.

\section{MATERIALS AND METHODS}

Study organism. Dilsea carnosa (Schmidel) O. Kuntze (1893) is a perennial subtidal red alga distributed throughout the arctic and temperate eastern Atlantic (Irvine 1995). It is very abundant along the Swedish west coast, where it grows at depths of around 5 to $20 \mathrm{~m}$ (Kylin 1944). The plant consists of a short stipe and a spoon-shaped blade up to $500 \mathrm{~mm}$ long and usually about half as broad at the widest part (Irvine 1995).

Natural fouling cover. A field survey was conducted to investigate if the previous field observations that had showed a very low fouling cover of Dilsea carnosa were representative. We randomly collected 5 individuals of $D$. carnosa and Laminaria digitata $(\mathrm{n}=5)$ from 2 localities (Saltö and Y. Vattenholmen) in the archipelago west of Tjärnö Marine Biological Laboratory on the west coast of Sweden. L. digitata was chosen since it is relatively similar in size and morphology to $D$. carnosa and grows at the same depths. The algae were collected at around $10 \mathrm{~m}$ depth by SCUBA diving. At both localities, a marked sinking line was dropped a few metres above the bottom where the algae were growing. Thereafter, 1 individual each of both $D$. carnosa and $L$. digitata lying in the proximity of a marking were collected at 5 different marks. After collection, 
the algae were transported to the laboratory for determination of the fouling intensity. The algae were photographed and the degree of fouling and the species composition of the fouling organisms were determined with the picture-analysing software ImageJ 1.32j (Wayne Rasband, National Institutes of Health, Bethesda, Maryland, USA).

Preparation of crude organic extract. Dilsea carnosa plants were collected in the archipelago west of Tjärnö Marine Biological Laboratory by SCUBA diving. After collection, the algal sample was taken back to the laboratory for immediate processing. The algal material was drained of excess water and a sub-sample was taken for volume measurement by displacement in a graduated cylinder filled with seawater. The subsample and the remaining algal material were freezedried, homogenised, and extracted 3 times with dichloromethane. The resulting solutions were filtered and the dichloromethane was removed by rotary evaporation. This procedure was repeated with 1:1 dichloromethane:methanol and then methanol, and all of the obtained extracts were combined to a single fraction. The resulting extract of the main sample was dried under a stream of nitrogen and stored in a $-70^{\circ} \mathrm{C}$ freezer until used in field assays. The extract of the sub-sample was transferred to a pre-weighed scintillation vial, dried under a stream of nitrogen and weighed. The weight of the sub-sample extract and the volume of the sub-sample were used to calculate a volume:dry weight extract ratio.

Preparation of gels. Antifouling effects were examined using the technique of Henrikson \& Pawlik (1995), in which the algal extract is incorporated into stable gels that serve as settlement substrata for field assays. Treatment gels were prepared by adding $0.4 \mathrm{~g}$ of Phytagel $^{\mathrm{TM}}$ to $20 \mathrm{ml}$ of distilled water and mixed thoroughly. The gel mixture was heated in a microwave oven until boiling and allowed to cool to $60^{\circ} \mathrm{C}$. An aliquot of extract, resuspended in $2.5 \mathrm{ml}$ of methanol, was stirred into the gel mixture until homogenous. The resulting mixture was then poured into $4 \mathrm{ml}$ Petri dishes (NUNC), so that the final concentration of extract was volumetrically equivalent to whole algal tissue. Control gels were prepared in a similar manner, except that $0.75 \mathrm{~g}$ of Phytagel was used instead of $0.4 \mathrm{~g}$. A higher concentration of the inert gelling agent was necessary to maintain equal gel hardness in treatment and control gels.

Diffusion of extracts. Extracts of Dilsea carnosa were used to assess the percentage retention of compounds in the gels over the time period that the field experiments lasted. We prepared 5 sets of 3 gels $(n=3)$ as detailed above. Of these 3 sets were placed in a flowthrough system in the laboratory, while 2 sets were retained as controls. The flow was adjusted so that the average current speed corresponded to $5 \mathrm{~cm} \mathrm{~s}^{-1}$, a speed obtained from current measurements in the field (P. R. Jonsson, K. M. Berntsson, A. I. Larsson unpubl.). The first control set was re-extracted immediately after being poured into the Petri dishes. The second control set was stored at $5^{\circ} \mathrm{C}$ in a plastic bag throughout the $33 \mathrm{~d}$ assay period and subsequently re-extracted to determine if storage affected the amount of extractable material. The remaining 3 sets were extracted after 7 , 18 and $33 \mathrm{~d}$ in the flow-through system, and the biomass of recovered extract was recorded. To compensate for salts absorbed by the gels in the flow-through system, the gels were macerated and rinsed in distilled water for $1 \mathrm{~h}$ before further extraction. The water was then filtered and used for conductivity measurements. From the obtained conductivity data, the mass of salts taken up by the gels was estimated. Since the rinsing procedure with water could potentially dissolve polar metabolites of the extract, the water was reduced by rotary evaporation. The remaining water was transferred to pre-weighed scintillation vials, dried in a Speed-Vac and weighed. The estimated masses of the salts were subtracted from the total masses, and the remaining masses were then added to the masses of the recovered extracts.

Field experiments with stable gels. The treatment gels and the control gels $(n=4$, except for the first time period, when the number of replicates was 5) were placed in the field by SCUBA diving at 4 localities (Grötholmen, Krugglö, Småholmarna and Y. Vattenholmen) and the gels were left in the field for a period of approximately $1 \mathrm{mo}$, for 7 different time periods. At each locality, the gels were tied to a fishing line, which had a weight and a float attached to each end. The treatment and control gels on the lines were randomly distributed, $2 \mathrm{~cm}$ spaces apart. The fishing lines were anchored at approximately $10 \mathrm{~m}$ depth at each locality. The floats kept the lines in an upward direction so that the distances between the bottom and the lowest and the highest positioned gels were approximately 15 and $60 \mathrm{~cm}$, respectively. The time periods for the field experiments were: 2 July to 26 August 2002 (FE1), 26 August to 24 September 2002 (FE2), 10 October to 19 November 2002 (FE3), 25 February to 26 March 2003 (FE4), 26 March to 30 April 2003 (FE5), 30 April to 12 June 2003 (FE6) and 12 June to 15 July 2003 (FE7). To be able to compare the fouling intensity on gels and living Dilsea carnosa plants, 6 to 10 unfouled individuals were marked in the vicinity $(\leq 5 \mathrm{~m})$ of the gels. This was done at each locality at the same time as the first sets of gels were put out (i.e. FE1), and since the fouling rates on the plants were generally very low for all field experiments except FE7, the same individuals were used for all the field experiments. At the end of each field experiment, the marked algae were visually 
examined in the field for macroscopic fouling organisms, while the gels were transported to the laboratory. In the laboratory, the degree of fouling and the species composition of the fouling organisms were recorded. Fouling intensity was measured as number of settled individuals or colonies. Only macroscopic fouling was recorded. At the end of the last field experiment (i.e. FE7), the marked algae were also transported to the laboratory for determination of fouling intensity. The algae were photographed, and the degree of fouling $\mathrm{dm}^{-2}$ algal surface area was measured with the picture-analysing software Image J 1.32j.

Inhibition of fouling by cuticle peeling. Because the extracts seemed to have limited effects on fouling, and because the settlement rate of certain fouling organisms on Dilsea carnosa during the last field experiment (i.e. FE7) was relatively high, chemical inhibition of recruitment seemed to be an inadequate explanation for the generally low fouling abundance found naturally on $D$. carnosa. Furthermore, we discovered during the field experiments that $D$. carnosa is able to slough off the outermost cell layer, which led us to hypothesize that the low degree of fouling on this alga is a result of cuticle peeling. To test this hypothesis, 17 and $20 \mathrm{D}$. carnosa plants were marked by SCUBA diving at 2 localities (Krugglö and Y. Vattenholmen) in the archipelago west of Tjärnö Marine Biological Laboratory in the middle of July 2003 (additionally, 3 and 4 plants were marked $4 \mathrm{wk}$ later). To allow us to detect a possible decrease in fouling, individuals with high fouling cover were chosen. The percentage cover of fouling on the marked algae was visually estimated in the field according to the following procedure: (1) individuals with fouling cover close to $0 \%$ were allocated a value of $0 \%$ if no fouling occurred and $1 \%$ if some fouling organisms were present on the algal thallus; (2) for individuals with more fouling, the algal thalli were divided into 4 similar-sized parts with an underwater whiteboard. The degree of fouling cover of each part was then visually determined and summed to obtain an estimate of total fouling cover. The marked algae were revisited 5 times during autumn and early winter, and on each occasion, the percentage cover of fouling was estimated. Additionally, the algae were examined for traces of cuticle peeling (i.e. milky epidermic layer loosely attached and/or partly shed; see Fig. 6B).

Statistical analyses. The homogeneity of variances for all the obtained data were tested with Cochran's $C$-test and transformed where required to fulfil the requirement of homogenous variances, before any further statistical analyzes were conducted (Underwood 1997). The data from the survey of natural fouling cover on Dilsea carnosa were arcsine-transformed and analyzed by 2-factorial analyses of variance (2-factor ANOVA) with algal species as a fixed factor and local- ity as a random factor. The data from the field experiments were root-transformed when required and analyzed by 2 -factor ANOVA followed by a StudentNewman-Keuls test (SNK test). The factors were 'treatment' (i.e. extract and control gels) (fixed) and 'locality' (random). Interactions between the factors that met the requirement for pooling $(p>0.25)$ were consequently pooled (Winer et al. 1991).

\section{RESULTS}

\section{Natural fouling cover}

The field survey confirmed the previous field observations, which had indicated that the epibiotic cover on Dilsea carnosa is generally low. The total fouling abundance on $D$. carnosa was significantly lower compared to that on Laminaria digitata (2-factor ANOVA, $\left.F_{1,17}=50.33, \mathrm{p}<0.0001\right)$, and the fouling cover at the 2 investigated localities (Saltö and Y. Vattenholmen) was on average 0.6 to $1.2 \%$ for $D$. carnosa and 32.0 to $34.4 \%$ for L. digitata (Fig. 1; see also Fig. 6A). The most common fouling organisms were the bryozoan species Electra pilosa and Membranipora membranacea (Fig. 2).

\section{Antifouling activity and diffusion of the extracts}

Overall, organic materials from the crude extract of the alga Dilsea carnosa diffused gradually from gels, with a mean of $29.8 \%$ of the initial material remaining after $33 \mathrm{~d}$ in the flow-through system. The colonisation results from the field experiments with the gels are

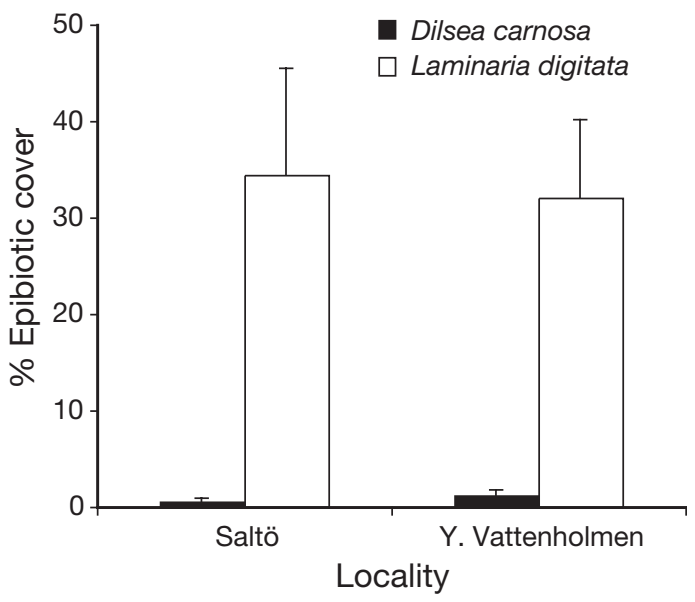

Fig. 1. Red alga Dilsea carnosa and brown alga Laminaria digitata. Epibiotic cover (\% of algal surface area) at 2 localities in the archipelago west of Tjärnö Marine Biological Laboratory. Data are means $+\mathrm{SE}_{;} \mathrm{n}=5$ 


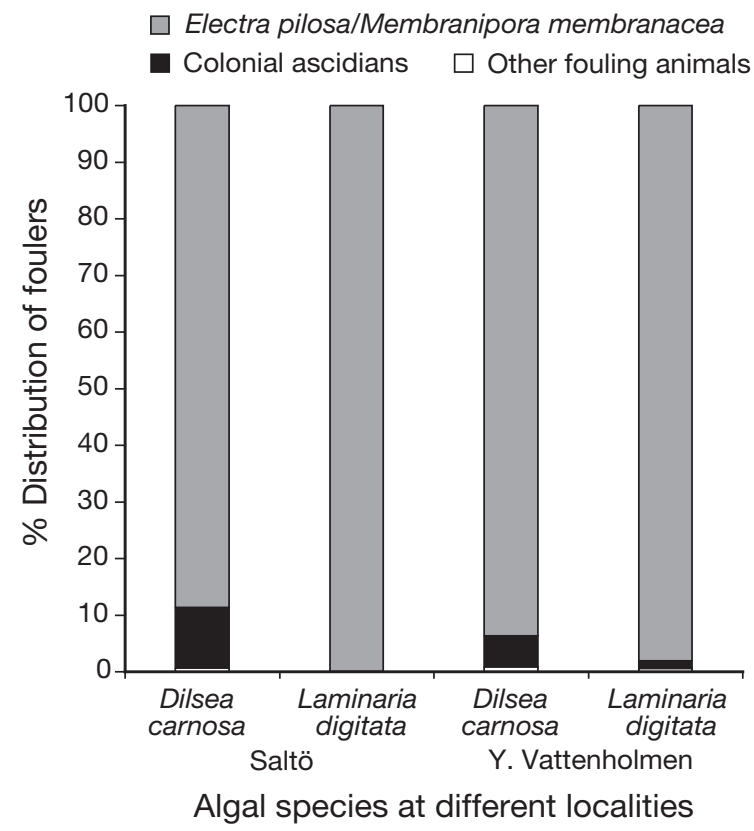

Fig. 2. Dilsea carnosa and Laminaria digitata. Percentage distribution of different fouling organisms on algae at 2 localities in the archipelago west of Tjärnö Marine Biological Laboratory shown in Table 1 and Figs. $3 \& 4$. The recruitment of fouling organisms on both treatment and control gels were too low and sporadic for meaningful statistical analyses at the end of Expts FE2, FE4, FE5 and FE6. During Expt FE1, high numbers of the brown alga Microsyphar sp. were recruited onto the gels, and at the end of the experiment a significantly higher abundance of this alga was found on control than on treatment gels (2-factor ANOVA, $F_{1,35}=15.92, \mathrm{p}=0.0003$; Fig. 3A). At the end of Expt FE3, the pennate diatom Licmophora sp. had recruited in relatively high numbers onto the gels at Grötholmen. At this locality, significantly more Licmophora sp. was found on control than on treatment gels (1-factor ANOVA, $F_{1,6}=180.50$, $\mathrm{p}<0.0001$; Fig. 3B). At the end of Expt FE7, benthic solitaire ciliates (Folliculinidae) had recruited onto the gels, with significantly more ciliates on the controls at the localities Grötholmen and Y. Vattenholmen (2-factor ANOVA, $F$ (interaction) $)_{1,3}=5.504, \mathrm{p}=0.005$, followed by SNK test on the interaction, $\alpha=0.05$; Fig. 3C). Additionally, the gels had a high abundance of the bryozoan species Electra pilosa and Membranipora membranacea. However, no differences in the number of bryozoan colonies between the treatment

Table 1. Dilsea carnosa. Major macroscopic fouling organisms found on gels and on marked plants at the termination of the field experiments FE1 to FE7, which were conducted at 4 localities and 7 different time periods during 2002 and 2003 . Results from statistical tests on differences in fouling between the treatment and the control gels are also shown (see 'Results' text for details). nt: degree of macroscopic fouling on the treatment and control gels too low for statistical comparisons

\begin{tabular}{|c|c|c|c|c|}
\hline & Time period & Fouling on gels & Fouling on algae & Statistical test \\
\hline \multirow[t]{3}{*}{2002} & $\begin{array}{l}2 \text { July to } \\
26 \text { August } \\
\text { (Expt FE1) }\end{array}$ & $\begin{array}{l}\text { Microsyphar sp. (brown alga), bryozoan } \\
\text { colonies (Electra pilosa/Membranipora } \\
\text { membranacea) and the polychaete } \\
\text { Pomatoceros triqueter on both control } \\
\text { and treatment gels }\end{array}$ & A few P. triqueter & $\begin{array}{l}\text { Significantly more } \\
\text { Microsyphar sp. on } \\
\text { controls }\end{array}$ \\
\hline & $\begin{array}{l}26 \text { August to } \\
24 \text { September } \\
\text { (Expt FE2) }\end{array}$ & $\begin{array}{l}\text { A few } P \text {. triqueter on both control and } \\
\text { treatment gels }\end{array}$ & A few P. triqueter & nt \\
\hline & $\begin{array}{l}10 \text { October to } \\
19 \text { November } \\
\text { (Expt FE3) }\end{array}$ & $\begin{array}{l}\text { Pennate diatoms (Licmophora sp.) and a few } \\
\text { E. pilosa/M. membranacea colonies on both } \\
\text { control and treatment gels }\end{array}$ & Only old $P$. triqueter & $\begin{array}{l}\text { Significantly more } \\
\text { Licmophora sp. on } \\
\text { controls }\end{array}$ \\
\hline \multirow[t]{4}{*}{2003} & $\begin{array}{l}25 \text { February to } \\
26 \text { March } \\
\text { (Expt FE4) }\end{array}$ & No fouling & $\begin{array}{l}\text { No fouling (no trace of old } \\
P . \text { triqueter). Cuticle peeling } \\
\text { was observed on several } \\
\text { plants }\end{array}$ & nt \\
\hline & $\begin{array}{l}26 \text { March to } \\
30 \text { April } \\
\text { (Expt FE5) }\end{array}$ & $\begin{array}{l}\text { A few E. pilosa/M. membranacea colonies } \\
\text { on both control and treatment gels }\end{array}$ & No fouling & nt \\
\hline & $\begin{array}{l}30 \text { April to } \\
\text { 12 June } \\
\text { (Expt FE6) }\end{array}$ & $\begin{array}{l}\text { A few E. pilosa/M. membranacea colonies } \\
\text { on both control and treatment gels }\end{array}$ & $\begin{array}{l}\text { A few E. pilosa/M. } \\
\text { membranacea colonies } \\
\text { (ca. } 1 \text { to } 2 \mathrm{dm}^{-2} \text { ) }\end{array}$ & nt \\
\hline & $\begin{array}{l}12 \text { June to } \\
15 \text { July } \\
\text { (Expt FE7) }\end{array}$ & $\begin{array}{l}\text { E. pilosa/M. membranacea and solitaire } \\
\text { benthic ciliates (Folliculinidae) }\end{array}$ & $\begin{array}{l}\text { On average } 22 \mathrm{E} . \\
\text { pilosa/M. membranacea } \\
\text { colonies } \mathrm{dm}^{-2}\end{array}$ & $\begin{array}{l}\text { Significantly more ciliates } \\
\text { (Folliculinidae) on controls; } \\
\text { no significant differences for } \\
\text { E. pilosa/M. membranacea } \\
\text { between treatment and } \\
\text { control gels }\end{array}$ \\
\hline
\end{tabular}




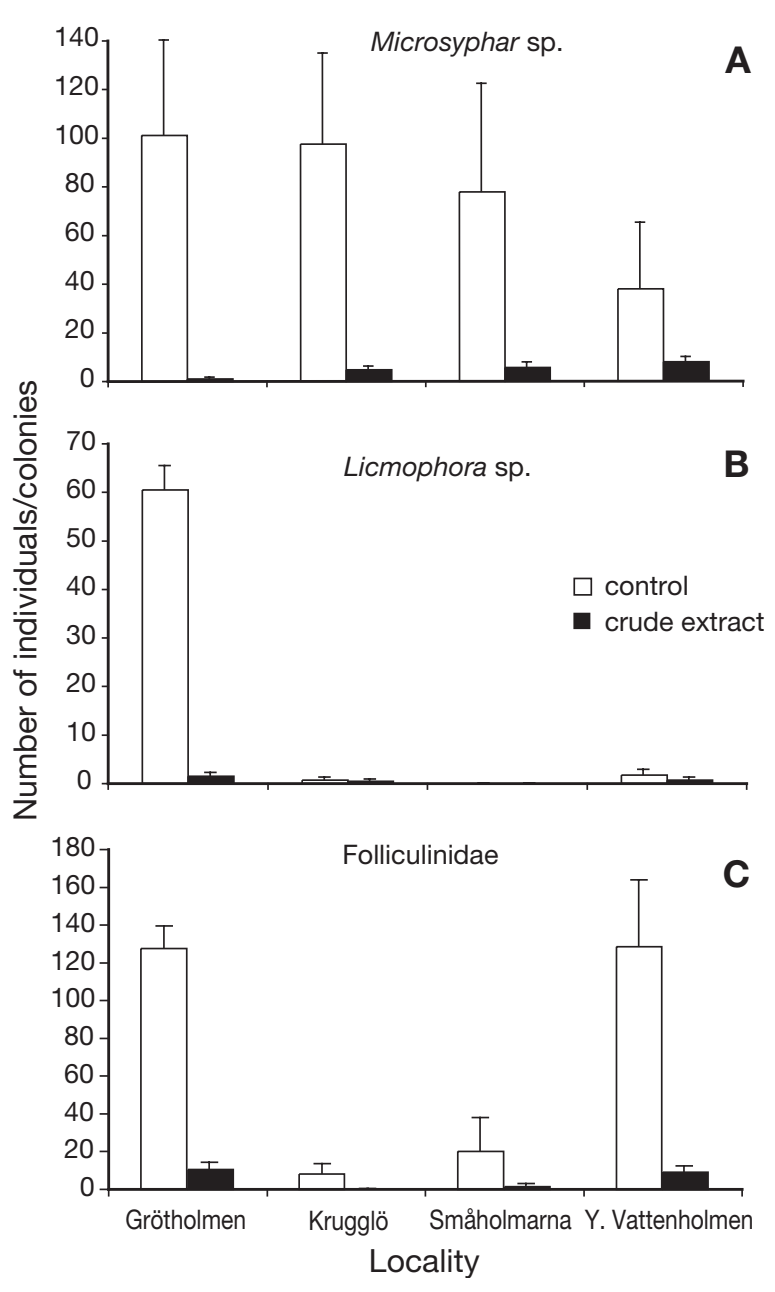

Fig. 3. (A) Brown alga Microsyphar sp. (Expt FE1); (B) benthic diatom Licmophora sp. (Expt FE3); (C) solitaire sessile ciliates (Folliculinidae) (Expt FE7). Number of individuals or colonies found on control gels and gels treated with crude extract of the red alga Dilsea carnosa at the end of the first (FE1), third (FE3) and the 7th (FE7) field experiments. Data are means $+\mathrm{SE}_{i} \mathrm{n}=5(\mathrm{~A}), 4(\mathrm{~B} \& \mathrm{C})$

and control gels could be detected (2-factor ANOVA, $F_{1,27}=0.009, p=0.93$; Fig. 4A). At the end of Expt FE7, $E$. pilosa and $M$. membranacea colonies had also recruited onto the marked algae. On average, only 1 to 2 bryozoan colonies $\mathrm{dm}^{-2}$ algal surface were found at the beginning of Expt FE7, while a mean of 22 colonies $\mathrm{dm}^{-2}$ were found at the end of Expt FE7 (Fig. 4B). No visual damage by grazing or any other mechanisms was apparent on any gels at the end of the field experiments.

\section{Inhibition of fouling by cuticle peeling}

We recovered 9 and 10 individuals from Krugglö and Y. Vattenholmen, respectively, at the end of the field

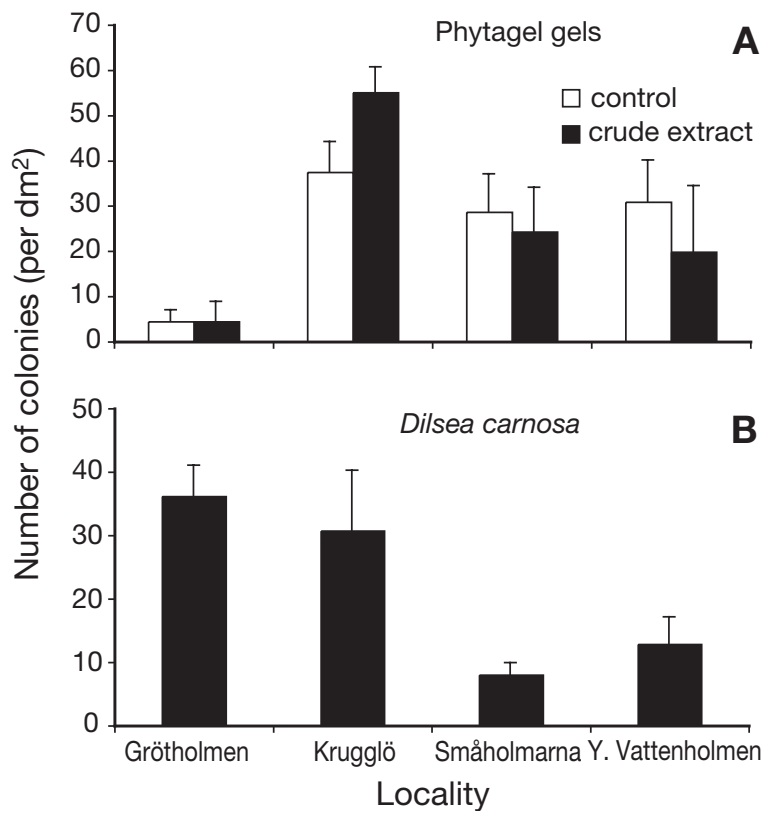

Fig. 4. Electra pilosa and Membranipora membranacea. Number of colonies $\mathrm{dm}^{-2}$ gel or algal surface of the bryozoans found on (A) control gels and gels treated with crude extract of the red alga Dilsea carnosa, or (B) marked D. carnosa plants at different localities at the end of the 7 th field experiment

(FE7). Data are means $+\mathrm{SE}_{i} \mathrm{n}=4$ (A), 5 (B)

survey. At the beginning of the investigation in July, the marked algae at both localities had a mean surface cover of epibiotic organisms of approximately 15 and $30 \%$, respectively (Fig. 5); 7 wk later, most of the marked algae had higher epibiotic surface cover. At the beginning of winter, surface cover had dropped to very low levels for most algal individuals. This drop did not occur at the same time at the 2 localities, but seemed to be delayed by about 1 mo at Y. Vattenholmen compared to Krugglö. Traces of cuticle peeling were observed on all algae that had experienced a radical drop in epibiotic surface cover, while no indications of cuticle peeling were observed on the other algal individuals (Fig. 6). During the whole investigation, the most common fouling organisms were the bryozoan species Electra pilosa and Membranipora membranacea.

\section{DISCUSSION}

\section{Mechanisms of inhibition of epibiotic recruitment by Dilsea carnosa}

Since restrictions of the use of toxic agents such as tributyltin (TBT) and copper in antifouling paints have been established, much research in marine chemical ecology has focused on finding new substances with antifouling 


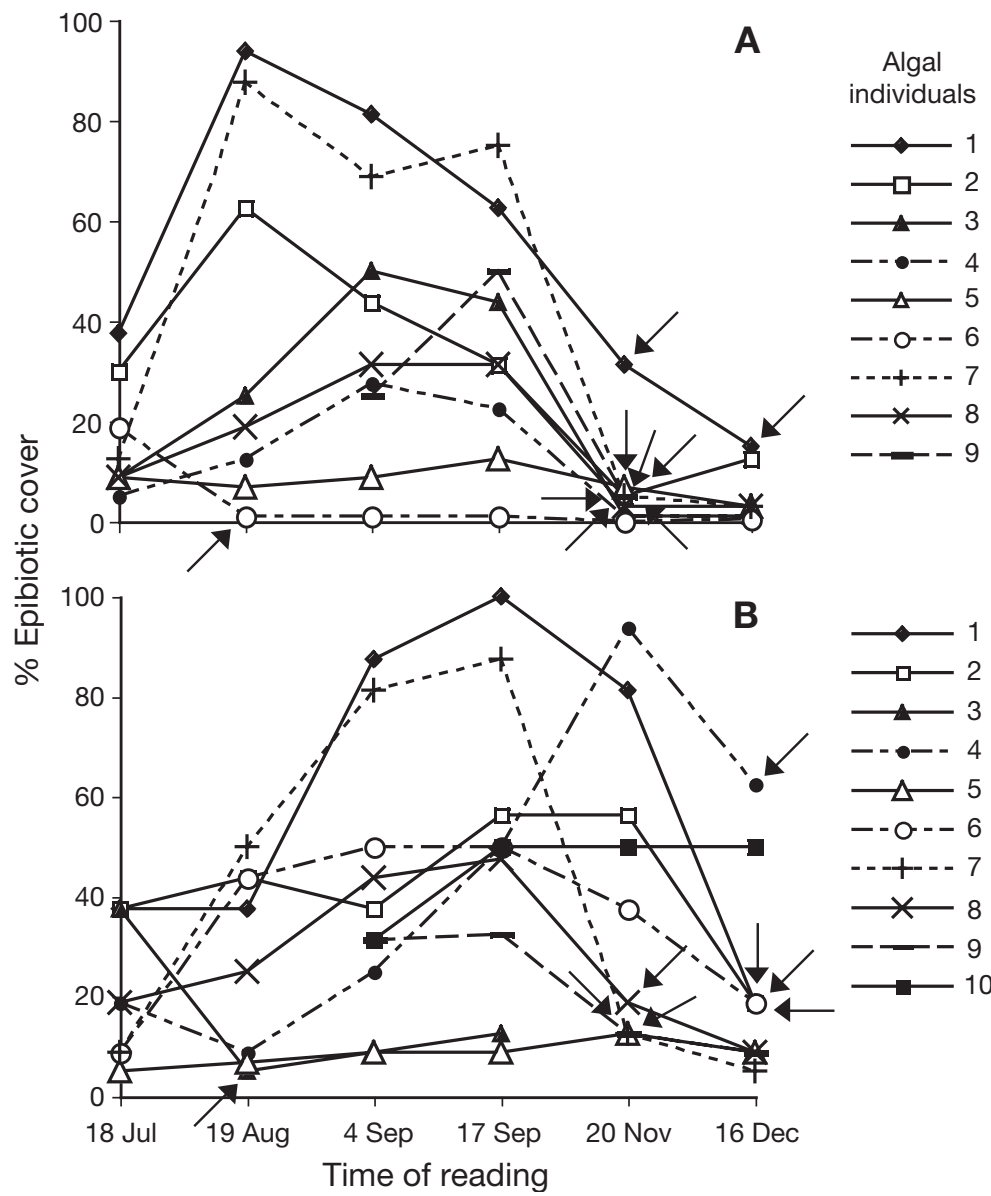

Fig. 5. Dilsea carnosa. Epibiotic cover (\% algal surface area) on marked individuals at (A) Krugglö and (B) Y. Vattenholmen in the archipelago west of Tjärnö Marine Biological Laboratory. Most algae were marked in late July 2003; exceptions were Individual 9 at Krugglö, and Individuals 9 and 10 at Y. Vattenholmen, which were marked at the beginning of September of the same year. Arrows indicate that traces of cuticle peeling were observed on algal individuals

activities. Undoubtedly, this has led to the discovery of many metabolites with antifouling properties against a wide variety of epibiotic organisms (Clare 1996, Rittschof 2001 [reviews]). However, most of these studies have been laboratory-oriented, whereby extracts or pure compounds have been tested against a few standard test organisms, often Balanus amphitrite and Bugula neritina, placed in small volumes of static water (e.g. de Nys et al. 1996, Konig et al. 1999, Lau \& Qian 2000). Although such tests may give valuable information about a compound's potential as an active agent in a commercial antifouling paint, the ecological relevance of these types of studies is questionable (Hay 1996). If the focus of the research is to find compounds that function as natural antifoulants, a more fruitful approach may be to use artificial substrates incorporated with crude extracts or pure compounds at potentially realistic concentrations and deployed in the field, where the gels are open to settlement by a nat- ural population of fouling organisms. Such an approach, based on the use of stable gels, was described by Henrikson \& Pawlik (1995), and has successfully been used in a few studies since then (Da Gama et al. 2002, 2003, Kubanek et al. 2002). The stable gel approach is advantageous in that (1) most compounds are slowly released to the surface and the surrounding water over a considerable period of time, and (2) testing in the field allows assays in a natural water flow containing the natural mixture of propagules that encounter the plant's surface (Hay et al. 1998).

Using the approach of crude algal extracts incorporated into stable gels, we were able to show that Dilsea carnosa contains metabolites that deter recruitment of some coexisting fouling organisms. The brown alga Microsyphar sp., the pennate diatom Licmophora sp. and benthic solitaire ciliates of the family Folliculinidae all recruited in significantly fewer numbers to gels treated with $D$. carnosa crude extracts than to control gels. The extract, however, had no effect on the recruitment of the bryozoan species Electra pilosa and Membranipora membranacea. These bryozoans are very important foulers on seaweeds on the Swedish west coast (Nylund 1999 and this study). Therefore, a chemical defence against Microsyphar sp., Licmophora sp. and ciliates of the family Folliculinidae alone does not adequately explain the low natural fouling cover of $D$. carnosa. The conclusion that the extract had no effect on the recruitment of E. pilosa and M. membranacea is based on the assumption that all active metabolites were presented to the fouling organisms at natural or higher concentrations during the field experiments with gels. The diffusion experiment showed that organic materials from the crude extract of D. carnosa diffused gradually from the gels. Nevertheless, it is possible that some active metabolites may have leached out of the gels in the first days of the experiment. Alternatively, metabolites may have degraded through oxidation during the $1 \mathrm{mo}$ duration of the field experiments. However, the lack of inhibition by $D$. carnosa metabolites against $E$. pilosa and $M$. membranacea is in accordance with the field experiments, which showed that relatively high numbers of these bryozoan species occasionally recruited onto $D$. carnosa plants at the same time as high numbers of E. pilosa and M. membranacea colonies recruited onto the gels. Thus, our conclusion is that the low degree of fouling naturally found on $D$. carnosa is not primarily a consequence of the production of secondary metabolites that chemically inhibit settlement of the dominating epibiotic organisms, but is most 

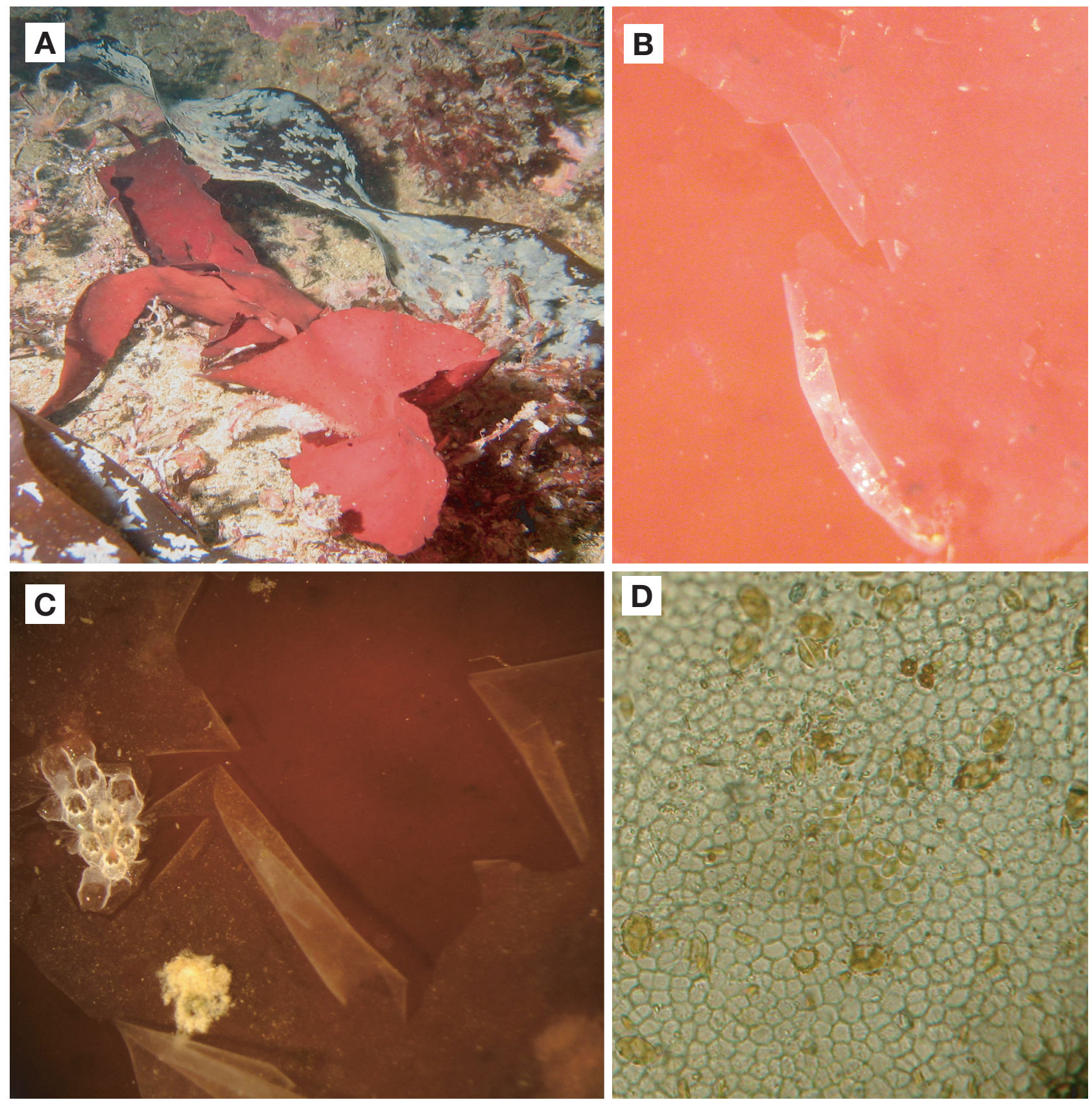

Fig. 6. Dilsea carnosa. Evidence for cuticle peeling. In the field, (A) D. carnosa is generally relatively clean of fouling compared to surrounding seaweeds (here the brown alga Laminaria digitata). (B) Traces of cuticle peeling are easily recognisable as a characteristic milky layer being sloughed off. (C) Those parts that have sloughed off the epidermis are completely unfouled, while the remainder may still be covered by epibiotic organisms (here the bryozoan Electra pilosa and the balanoid Verruca stroemia). (D) Microscopic examination reveals that the peeled cuticle layer of D. carnosa is 1 cell layer thick

likely due to processes working on the post-settlement stages of the colonizing organisms (cf. Wikström \& Pavia 2004).

During the field experiments with gels, we observed that individual Dilsea carnosa occasionally lost an outermost cell layer by sloughing. This observation, coupled with the lack of chemical inhibition towards dominant fouling organisms detected in our gel experiments, led us to hypothesise that the lack of fouling on $D$. carnosa could be a result of cuticle peeling. This hypothesis was tested in a field survey, and the results showed that algal individuals displaying a radical drop in fouling cover bore distinct traces of cuticle peeling. A co-occurrence of a radical drop in fouling with evi- 
dence of cuticle peeling was observed on all surveyed plants at both localities investigated. We do not know how often and regularly D. carnosa sheds its epidermis. The present study suggests that 2 major shedding events occur during late autumn and early spring. However, cuticle peeling by $D$. carnosa at other times has also been observed (Nylund pers. obs.). Even if shedding occurs relatively rarely (e.g. a few times each year), it may be an effective mechanism for removing a significant part of fouling organisms. Especially in temperate regions with a strong seasonal distribution of fouling organisms, a few properly timed shedding events may be enough to prevent overgrowth by major fouling organisms.

Sloughing of surface tissue has also been reported in other studies, and seems to be particularly common in coralline algae (Masaki et al. 1984, Johnson \& Mann 1986, Keats et al. 1993, Pueschel \& Miller 1996, Keats et al. 1997). Additionally, it has been observed in other red algae (Sieburth \& Tootle 1981, Gonzalez \& Goff 1989), in brown algae (Filion-Myklebust \& Norton 1981, Sieburth \& Tootle 1981, Moss 1982) and in green algae (Borowitzka \& Larkum 1977, McArthur \& Moss 1977). Most of these previous studies, however, have observed cuticle peeling only in the laboratory without testing its occurrence or ecological significance under natural conditions. To our knowledge, only 2 exceptions exist. Johnson \& Mann (1986) showed that fleshy algae recruited significantly less to boulders covered with the coralline alga Phymatolithon (which frequently sloughs off epithallial cells) than to bare boulders; however, the possibility that chemical inhibition was also involved could not be ruled out. In another study, Keats et al. (1997) showed that 3 coralline algae successfully removed associated fouling organism by shedding of epithallial cells in the field. Again, the possibility that chemical inhibition was also involved cannot be ruled out, since bleach-killed corallines were used as controls. This possibility is supported by the results of Degnan \& Johnson (1999), which showed that 1 of the algae investigated by Keats et al. (1997) chemically inhibits settlement and metamorphosis of an ascidian species. Since macroalgae in general are known to be rich in secondary metabolites (e.g. Tringali 1997, Faulkner 2002), it is important to try to distinguish the effects of non-chemical mechanisms that inhibit fouling, such as cuticle peeling, from chemical inhibition of fouling. The present study suggests that chemical inhibition of fouling is not the most important factor in explaining the low epiphytic abundance found naturally on Dilsea carnosa, but that this is probably a consequence of a mechanical defence aimed at the post-settlement stages of the colonising organisms, whereby the alga sloughs off its epidermis in order to remove associated epibiota.

\section{Is chemical inhibition of fouling by seaweeds a rare phenomenon?}

Based on the many investigations showing chemical antifouling activities in seaweeds, one could obtain the impression that the production of secondary metabolites to inhibit fouling and thus prevent overgrowth by other organisms is a common strategy in seaweeds. However, to our knowledge, an ecological antifouling role of secondary metabolites has only been successfully demonstrated for 2 seaweed species (i.e. Schmitt et al. 1995, Steinberg et al. 2001 and references therein). This could be due to 1 of 3 factors: (1) Research has focused on identifying natural antifouling compounds to control fouling from the perspective of application rather from an ecological perspective. (2) Secondary metabolites with natural antifouling roles are common in seaweeds, and although research has focused on identifying such metabolites, insufficient progress has been made: for a metabolite to be classed as a natural antifoulant, it must be shown that it is present on the surface of the producing organism, or released at a concentration sufficient to deter ecologically relevant fouling organisms (Davis et al. 1989, Hay 1996); this often requires a complex combination of chemical and experimental studies. (3) Chemical deterrence of fouling through production of secondary metabolites is a relatively uncommon phenomenon in seaweeds. If this is true, many of the reports of algal metabolites with antifouling activities may simply be a consequence of studies demonstrating biological activity of metabolites that in nature never reach the surface of the producing organism, or are never released to the surrounding water, or are lost so quickly by diffusion that they cannot affect epiphytes. In a study in which the antifouling activities of 10 species of chemically rich algae were tested, the surface extract from only 1, the red alga Delisea pulchra, significantly inhibited settlement of bryozoan larvae at either the average or twice the average natural concentrations (Steinberg et al. 2001). Although a limited number of species were tested against only 1 epibiotic organism, the data of Steinberg et al. (2001) support the suggestion that chemical deterrence of fouling by the production of secondary metabolites may be a relatively uncommon phenomenon in seaweeds. If chemical defence against fouling is uncommon, other mechanisms must be responsible for the low epibiotic cover found on many seaweed species. Such mechanisms may be mechanical defences such as cuticle peeling or physiological responses such as oxidative bursts, whereby large amounts of activated oxygen species are produced and rapidly released in response to an attack by a fouling organism (Collen et al. 1995, Weinberger et al. 1999, Weinberger \& Friedlander 2000). 
More studies are needed that focus on finding ecologically relevant antifoulants, whereby alternative explanations of why an alga has low epibiotic cover must also be evaluated before any firm conclusions about the prevalence of different antifouling mechanisms in seaweeds can be drawn.

In conclusion, this study has shown that crude extracts of the red alga Dilsea carnosa have no significant effect on the recruitment of bryozoans, the most important fouling organisms in habitats were $D$. carnosa is found. Instead, the low degree of fouling found naturally on D. carnosa is probably a consequence of a mechanical defence, whereby the alga sloughs off its outermost cell layer in order to remove associated epibiota. These findings, together with many other reports on the shedding of epithallial cells by algae, suggest that cuticle peeling may be a common strategy of marine macroalgae to avoid overgrowth by other organisms.

Acknowledgements. We are grateful to G. Cervin, B. Källström and E. Selander for diving support during the field experiments. We also thank the staff at the Tjärnö Marine Biological Laboratory for their good advice and contribution to a creative and happy working atmosphere. This research was supported by the European Union through the European Regional Development Fund (ERDF) Objective 2 West Sweden and by The Swedish Research council through contract 621-2002-289. The experiments performed in this study comply with current Swedish laws.

\section{LITERATURE CITED}

Bernstein BB, Jung N (1979) Selective pressures and coevolution in a kelp canopy community in southern California USA. Ecol Monogr 49:335-355

Borowitzka M, Larkum A (1977) Calcification in the green alga Halimeda. I. An ultrastructural study of thallus development. J Phycol 13:6-16

Brawley SH (1992) Mesoherbivores. In: John DM, Hawkins SJ, Price JH (eds) Plant-animal interaction in the marine benthos. Systematics Association special volume No. 46. Clarendon Press, Oxford, p 235-263

Cho JY, Kwon EH, Choi JS, Hong SY, Shin HW, Hong YK (2001) Antifouling activity of seaweed extracts on the green alga Enteromorpha prolifera and the mussel Mytilus edulis. J Appl Phycol 13:117-125

Clare AS (1996) Natural product antifoulants: status and potential. Biofouling 9:211-229

Collen J, Delrio MJ, Garciareina G, Pedersen M (1995) Photosynthetic production of hydrogen peroxide by Ulva rigida C. Ag. (Chlorophyta). Planta 196:225-230

Da Gama BAP, Pereira RC, Carvalho AGV, Coutinho R, Yoneshigue-Valentin Y (2002) The effects of seaweed secondary metabolites on biofouling. Biofouling 18:13-20

Da Gama BAP, Pereira RC, Soares AR, Teixeira VL, Yoneshigue-Valentin Y (2003) Is the mussel test a good indicator of antifouling activity? A comparison between laboratory and field assays. Biofouling 19:161-169

D'Antonio CD (1985) Epiphytes on the rocky intertidal red alga Rhodomela larix (Turner) C. Agardh: negative effects on the host and food for herbivores? J Exp Mar Biol Ecol 86:197-218

Davis A, Targett N, McConnell O, Young C (1989) Epibiosis of marine algae and benthic invertebrates: natural products chemistry and other mechanisms inhibiting settlement and overgrowth. In: Scheuer PJ (ed) Bioorganic marine chemistry, Vol 3. Springer-Verlag, Berlin, p 85-114

Degnan BM, Johnson CR (1999) Inhibition of settlement and metamorphosis of the ascidian Herdmania curvata by non-geniculate coralline algae. Biol Bull (Woods Hole) 197:332-340

de Nys R, Steinberg PD, Willemsen P, Dworjanyn SA, Gabelish CL, King RJ (1995) Broad spectrum effects of secondary metabolites from the red alga Delisea pulchra in antifouling assays. Biofouling 8:259-271

de Nys R, Leya T, Maximilien R, Afsar A, Nair PSR, Steinberg PD (1996) The need for standardised broad scale bioassay testing: a case study using the red alga Laurencia rigida. Biofouling 10:213-224

Dixon J, Schroeter SC, Kastendiek J (1981) Effects of the encrusting bryozoan, Membranipora membranacea, on the loss of blades and fronds by the giant kelp, Macrocystis pyrifera (Laminariales). J Phycol 17:341-345

Faulkner DJ (2002) Marine natural products. Nat Prod Rep 19:1-48

Filion-Myklebust C, Norton TA (1981) Epidermis shedding in the brown seaweed Ascophyllum nodosum and its ecological significance. Mar Biol Lett 2:45-52

Gonzalez MA, Goff LJ (1989) The red algal epiphytes Microcladia coulteri and Microcladia californica (Rhodophyceae, Ceramiaceae). II. Basiphyte specificity. J Phycol 25:558-567

Hay ME (1996) Marine chemical ecology: what's known and what's next? J Exp Mar Biol Ecol 200:103-134

Hay ME, Stachowicz J, Cruz-Rivera E, Bullard S, Deal M, Lindquist N (1998) Bioassays with marine and freshwater macroorganisms. In: Haynes KF, Millar JG (eds) Methods in chemical ecology, Vol 2. Bioassay methods. Kluwer, Boston, MA, p 39-141

Henrikson AA, Pawlik JR (1995) A new antifouling assay method: results from field experiments using extracts of 4 marine organisms. J Exp Mar Biol Ecol 194:157-165

Hurd CL, Durante KM, Harrison PJ (2000) Influence of bryozoan colonization on the physiology of the kelp Macrocystis integrifolia (Laminariales, Phaeophyta) from nitrogen-rich and -poor sites in Barkley Sound, British Columbia, Canada. Phycologia 39:435-440

Irvine LM (1995) Seaweeds of the British Isles, Vol 1. Rhodophyta, Part 2A. Cryptonemiales (sensu stricto), Palmariales, Rhodymeniales. Natural History Museum, London

Johnson CR, Mann KH (1986) The crustose coralline alga, Phymatolithon Foslie, inhibits the overgrowth of seaweeds without relying on herbivores. J Exp Mar Biol Ecol 96: $127-146$

Karez R, Engelbert S, Sommer U (2000) 'Co-consumption' and 'protective coating': two new proposed effects of epiphytes on their macroalgal hosts in mesograzerepiphyte-host interactions. Mar Ecol Prog Ser 205:85-93

Keats DW, Groener A, Chamberlain YM (1993) Cell sloughing in the littoral zone coralline alga, Spongites yendoi (Foslie) Chamberlain (Corallinales, Rhodophyta). Phycologia 32:143-150

Keats DW, Knight MA, Pueschel CM (1997) Antifouling effects of epithallial shedding in three crustose coralline algae (Rhodophyta, Coralinales) on a coral reef. J Exp Mar Biol Ecol 213:281-293

Konig GM, Wright AD, de Nys R (1999) Halogenated 
monoterpenes from Plocamium costatum and their biological activity. J Nat Prod (Lloydia) 62:383-385

Kubanek J, Whalen KE, Engel S, Kelly SR, Henkel TP, Fenical W, Pawlik JR (2002) Multiple defensive roles for triterpene glycosides from 2 Caribbean sponges. Oecologia 131: 125-136

Kylin H (1944) Die Rhodophyceen der Schwedischen Westküste. K Fysiogr Sällsk Handl 55, p 33

Lau SCK, Qian PY (1997) Phlorotannins and related compounds as larval settlement inhibitors of the tube-building polychaete Hydroides elegans. Mar Ecol Prog Ser 159: 219-227

Lau SCK, Qian PY (2000) Inhibitory effect of phenolic compounds and marine bacteria on larval settlement of the barnacle Balanus amphitrite amphitrite Darwin. Biofouling 16:47-58

Masaki T, Fujita D, Hagen N (1984) The surface ultrastructure and epithallium shedding of crustose coralline algae in an 'Isoyake' area of southwestern Hokkaido, Japan. Hydrobiologia 116/117:218-223

McArthur D, Moss B (1977) The ultrastructure of cell walls in Enteromorpha intestinalis (L.) Link. Br Phycol J 12:359-368

Moss B (1982) The control of epiphytes by Halidrys siliquosa (I.) Lyngb. (Phaeophyta, Cystoseriaceae). Phycologia 21: 185-191

Nylund GM (1999) Epibiosis of red algae and algal metabolites as settlement inhibitors of the barnacle Balanus improvisus Darwin. MS thesis, Göteborg University, Göteborg

Nylund GM, Pavia H (2003) Inhibitory effects of red algal extracts on larval settlement of the barnacle Balanus improvisus. Mar Biol 143:875-882

Pueschel CM, Miller TJ (1996) Reconsidering prey specializations in an algal-limpet grazing mutualism: epithallial cell development in Clathromorphum circumscriptum (Rhodophyta, Corallinales). J Phycol 32:28-36

Rittschof D (2001) Natural product antifoulants and coatings development. In: McClintock JB, Baker BJ (eds) Marine chemical ecology. CRC Press, Boca Raton, FL, p 543-566

Schmitt TM, Hay ME, Lindquist N (1995) Constraints on chemically mediated coevolution: multiple functions for seaweed secondary metabolites. Ecology 76:107-123

Seed R (1985) Ecological pattern in the epifaunal communi-

Editorial responsibility: Otto Kinne (Editor-in-Chief),

Oldendorf/Luhe, Germany ties of coastal macroalgae. In: Moore PG, Seed R (eds) The ecology of rocky coasts. Hodder \& Stoughton, London, p 22-35

Sieburth JM, Tootle JL (1981) Seasonality of microbial fouling on Ascophyllum nodosum (L.) Lejol., Fucus vesiculosus L., Polysiphonia lanosa (L.) Tandy and Chondrus crispus Stackh. J Phycol 17:57-64

Steinberg PD, de Nys R, Kjelleberg S (1998) Chemical inhibition of epibiota by Australian seaweeds. Biofouling 12: 227-244

Steinberg PD, De Nys R, Kjelleberg S (2001) Chemical mediation of surface colonization. In: McClintock JB, Baker BJ (eds) Marine chemical ecology. CRC Press, Boca Raton, FL, p 355-387

Tringali C (1997) Bioactive metabolites from marine algae: recent results. Curr Org Chem 1:375-394

Underwood AJ (1997) Experiments in ecology: their logical design and interpretation using analysis of variance. Cambridge University Press, Cambridge

Wahl M, Hay ME (1995) Associational resistance and shared doom: effects of epibiosis on herbivory. Oecologia 102: $329-340$

Walters LJ, Hadfield MG, Smith CM (1996) Waterborne chemical compounds in tropical macroalgae: positive and negative cues for larval settlement. Mar Biol 126:383-393

Weinberger F, Friedlander M (2000) Response of Gracilaria conferta (Rhodophyta) to oligoagars results in defense against agar-degrading epiphytes. J Phycol 36:1079-1086

Weinberger F, Friedlander M, Hoppe HG (1999) Oligoagars elicit a physiological response in Gracilaria conferta (Rhodophyta). J Phycol 35:747-755

Wikström S, Pavia H (2004) Chemical settlement inhibition versus post-settlement mortality as an explanation for differential fouling of 2 congeneric seaweeds. Oecologia 138: $223-230$

Williams GA, Seed R (1992) Interactions between macrofaunal epiphytes and their host algae. In: John DM, Hawkins SJ, Price JH (eds) Plant-animal interaction in the marine benthos. Systematics Association special volume No. 46. Clarendon Press, Oxford, p 189-211

Winer B, Brown D, Michels K (1991) Statistical principles in experimental designs. McGraw-Hill, New York

Submitted: December 9, 2004; Accepted: March 8, 2005

Proofs received from author(s): August 5, 2005 